investigación económica, vol. LXXI, 280, abril-junio de 2012, pp. 23-54

\title{
Two Critics of Marginalist Theory: Piero Sraffa and John Maynard Keynes
}

Heinz D. KuRZ*

\section{INTRODUCTION}

John Maynard Keynes and Piero Sraffa were arguably the most important critics of what was at their time, and in some new version is again today, marginalist or neoclassical economic theory. Why were they critical of this theory? What is the relationship between their criticisms? Were these similar, complementary or contradictory? With regard to developments in economics after Keynes we may ask: How does Sraffa's contribution compare with PostKeynesian economics? It is far from self-evident that his contribution ought to be reckoned as belonging broadly to Post-Keynesianism, and there are voices maintaining that it should not. Interestingly they come both from the camp of advocates of Post-Keynesianisms of all sorts and from the camp of its critics. Marc Lavoie (2010) pointed out that amongst Post-Keynesians there

Submitted September 2011; accepted March 2012.

* Department of Economics and Graz Schumpeter Centre, University of Graz, Austria, <heinz. kurz@uni-graz.at>. This paper is a revised version of an entry I contributed to the Handbook of Post-Keynesian Economics, edited by Geoff Harcourt (2012). I should like to thank Christian Gehrke, Geoff Harcourt, John King and Ignacio Perrottini for valuable comments on an earlier draft of the paper. Thanks are also due to two anonymous referees of Investigación Económica. 
is a group that wishes to distance itself from Sraffa and those working in his tradition. And Christopher Bliss (2010: 636), a critic of Post-Keynesianism, contended that Sraffa "had little continuing interest in macroeconomics" -"to call him a post-Keynesian is anomalous."

In this paper I compare important elements of Sraffa's analysis and his criticism of marginalist theory with elements of Keynes's analysis and criticism. It will be argued that in terms of certain crucial ideas there are sufficiently close links between Sraffa's viewpoint and the viewpoints of Keynes and of some Post-Keynesians, whereas with regard to some other ideas there are fundamental differences. Against the background of Ludwig Wittgenstein's observation that to try to define philosophical systems in travail is like trying to define clouds by their shape, one can perhaps say that Post-Keynesianism is an economic line of thinking or approach in travail, which at present is characterized by a set of convictions shared by its proponents, but which lacks overall coherence. ${ }^{1}$ There is the famous joke that when ten economists are asked to come up with their views on a particular subject, eleven opinions will be presented, two coming from Mr. Keynes. I am inclined to think that with regard to Post-Keynesians the situation is worse (or better, just as you like). There is, however, a strong bond uniting Post-Keynesians of various brands and Sraffa: it is their opposition to the marginalist or neoclassical theory (see also Kurz and Salvadori, 2010a). The latter revolves basically around two closely interrelated ideas, one regarding the determination of the volume of output as a whole and the other regarding the sharing out of that output amongst different claimants: First, there is 'Say's law' conceived of as the tendency of the market economy, if left to itself, towards the full employment of labour and the full utilization of the capital stock. Secondly, there is the idea that the proprietors of the productive factors are remunerated according to the factors' marginal contributions to the product. While Keynes and his followers directed their attention and energy first and foremost to a criticism of the first idea, Sraffa and his followers did so with respect to the second one. This division of labour between the two groups of critics of marginalist theory may, but need not, involve a division of view,

\footnotetext{
1 See the early survey by Hamouda and Harcourt (1988).
} 
although attempts to integrate into a coherent whole what took off from different starting points turned out to be all but simple.

The composition of the paper is the following. Section 2 counterposes the classical and the marginalist approach to the theory of value and distribution, as Sraffa saw them, and provides a summary account of his main criticisms of the latter. Section 3 deals briefly with the route by which Sraffa arrived at his results, which sheds additional light on his critical task. The section is based on Sraffa's unpublished work. Obviously, only a small part of his respective work can be surveyed. Section 4 draws out the implications of these criticisms with regard to his view of the working of the economic system, that is to say, as regards the determination of output as whole and employment. According to Sraffa the capitalist economy is not the crisis-free system possessed of an endogenous mechanism of selfregulation as it is described by marginalist theory. Section 5 contains some concluding observations.

\section{SRAFFA'S CRITICISM OF THE MARGINALIST THEORY OF VALUE AND DISTRIBUTION}

In the preface of his book (and even in the book's subtitle) Sraffa is very clear about its critical objective: the propositions in the book are explicitly designed "to serve as the basis for a critique of [the marginalist theory of value and distribution]" (1960: vi). He is also very clear about the origin of his propositions: they derive from "the standpoint $[\ldots]$ of the old classical economists from Adam Smith to Ricardo" (1960: v) and consist in a coherent reformulation of this standpoint, shedding its earlier weaknesses and developing its strengths. By reformulating the classical theory of value and distribution Sraffa at the same time sought to provide a foil against which the shortcomings of the marginalist theory can be put into sharp relief. We might qualify Sraffa's respective intellectual enterprise thus as reflecting Spinoza's determinatio est negatio. ${ }^{2}$

2 Against this evidence one can only wonder what makes Bliss (2010: 636) contend that Sraffa "could not come up with a complete alternative to the classical theory that he disliked." 


\section{Alternative roles of counterfactuals}

In the preface Sraffa also emphasizes the main substantive difference between the classical and the marginalist analytical approach, as he sees it. The former analyses a given system of production actually in use, specified in terms of the actual gross outputs of the various commodities produced and the methods of production actually employed to do this plus the magnitude of one of the distributive variables, the real wage rate or, alternatively, the share of wages in the social product (or the general rate of profits). On the basis of these givens the classical authors determined the other distributive variable (and the rents of land) and relative prices. It is only after having established the mathematical properties of a given system of production with regard to the constraint binding changes of the distributive variables and the associated changes in relative prices that the classical authors turned to the problem of the choice of technique from a set of alternatives available to cost-minimizing producers. This choice is then shown to depend on income distribution.

The marginalist authors tried instead to understand a given system of production by analysing another, adjacent system, taken to be only marginally different from it. This is reflected in their method of contemplating the presumed effects of hypothetical incremental changes "in the scale of an industry or in the "proportions of the factors of production"' (1960: v). The marginalist approach thus involves as a part and parcel of the method employed the invocation of a very particular counterfactual reasoning, reflected in such concepts as the marginal utility of a commodity and especially the marginal productivity of a factor. ${ }^{3}$ Translated into the

3 Bliss (2010: 636) misses Sraffa's point when he writes: "Sraffa's claim that because the [classical] model is unchanging marginal concepts are inapplicable looks like a simple mistake. Counterfactual changes can be imagined and their consequences worked out, as in standard linear programming." The point is that the classical approach does not need to invoke counterfactual changes in order to determine the general rate of profits and relative prices of a given system of production, whereas by construction the marginalist approach is bound to invoke a very particular kind of counterfactuals in order to accomplish the task. As will be seen in the following, it is the kind of counterfactuals under consideration that Sraffa found highly problematic. It goes without saying that the classical 
framework of a choice of technique and thus a choice amongst alternative systems of production, the marginalist approach focuses attention entirely on the hypothetical existence of a system adjacent to the actual one or, more precisely, on the existence of a switchpoint between the two systems (and actually a continuum of such switchpoints between systems). The characteristic feature of switchpoints is that both distributive variables, wages, $w$, and the rate of profits, $r$, are rigidly fixed and are the same in both systems. Sraffa found this marginalist presupposition unacceptable. In a note written on 15 December 1943 he stressed that the

so-called determination is due to circumstances, which exist, not in the real world of actual production, but only in the world of imagination and possibilities: they are not intrinsic to the [actual] system and other levels [of $w$ and $r$ ] cannot be 'inconsistent' with it. As far as the real, existing, system described by the equations is concerned, any levels [of $w$ and $r$ ] are consistent with it (Sraffa Papers, D3/12/35: 43).

The question is close at hand, whether the choice of technique argument supports the marginalist intuition that the rate of profits (the real wage rate) can be conceived of as reflecting the marginal productivity of physical capital (labour) and whether the ratio of the two distributive variables moves inversely with the ratio of the quantities of the two factors of production. If the question was to be answered in the positive, then for any given endowment of the economy of capital and labour, given technical alternatives and given preferences of consumers, income distribution and

approach is not per se opposed to, or incompatible with, counterfactual reasoning, as Sraffa makes clear, for example, with regard to the implications of technical change in basic or non-basic industries for income distribution and relative prices; see Sraffa (1960: 7-8). This is supported by Sraffa's unpublished work. In a note written in summer 1928 Sraffa emphasizes: "The question asked of the theory of value is the following: Given (from experience) the prices of all commodities [...], find a set of conditions that will make these prices appear to be necessary. This means, given the unknowns, find the equations (i.e. the constants) [...] But this is the general question, the problem of finding the theory of value: when it is solved, once and for all, the particular questions asked are the reverse, i.e. given the constant equations, if the value of one of the constants is varied, how are the resultant prices determined?” (Sraffa Papers, D3/12/9: 65). 
relative prices (and the quantities produced) would be fully determined. In this case the particular counterfactuals invoked by the marginalist authors, especially the concept of the marginal productivity of capital, would be fully justified and the basic intuition guiding the approach, confirmed.

\section{The revival of the classical approach}

Sraffa's achievements now consist in the following. On the constructive side he showed that the classical approach was perfectly sound and allowed us to determine the general rate of profits and relative prices in terms of the system of production actually in use and the real wage rate or, alternatively, the share of wages in the social product. No other determinants were needed and no other "forces" such as demand and supply functions had to be invoked. Scarce natural resources, such as land, fixed capital and joint production did not constitute insurmountable obstacles to the approach, as some earlier critics had maintained. ${ }^{4}$ The analysis also did not depend on any restrictive assumption regarding the employment of productive factors (especially labour). There is no presumption that the work force of society is fully employed. (Both even a casual observation of real economies and, as we will see below, theoretical considerations speak in favour of not prejudicing the analysis by focusing attention only on economic systems in which the services of all productive factors are permanently fully employed or close to full employment.) The classical approach draws attention to the main factors regulating income distribution and relative prices: technical knowledge embodied in the methods of production available to cost-minimizing producers at a given time, the amounts and qualities of natural resources at the disposal of society and the real wage rate (or share of wages), which is seen as an outcome of the "scramble for the surplus" (Sraffa Papers, D3/12/11: 83). Changes in these factors are identified as the main causes over time of changes in income distribution and relative prices. If we take Adam Smith's concept of an ever deeper division of labour seriously, as

\footnotetext{
${ }^{4}$ For a discussion of some of the intricate problems involved, see Kurz and Salvadori (1995).
} 
Sraffa did, then actual changes in output levels are accompanied by learning effects and typically entail changes in the system of production in use, i.e. changes in the methods of production actually employed. Concerned with reviving the standpoint of the old classical economists, Sraffa in his analysis therefore could not have recourse to constant returns to scale; viz. his explicit warning that no such assumption is entertained (Sraffa, 1960: vi). ${ }^{5}$

\section{The difficulty besetting the marginalist notion of capital}

On the critical side, Sraffa stressed the difficulties besetting the marginalist approach. First, by proceeding in terms of hypothetical marginal changes it entered unknown territory and had to come up with concepts, the meaning of which was dubious or misleading. In consumer theory the concept of marginal utility introduced expectations into the analysis, because the benefits consumers derive from a marginal increase in the consumption of a particular good cannot be known a priori; it is an expected magnitude. Such expectations may, or may not, be met, and in case they are not met, they may change swiftly. The equilibrium contemplated by the marginalist theory therefore of necessity applies only to expected states and not to actual ones and may be fitful. More important, it is unclear what is meant by a marginal increase in the "quantity of capital" employed in the economy, given the employments of all other productive factors, labour and land. In order to be consistent with the rest of the analysis, the increase had to be in physical terms and had to leave untouched the size and composition of the capital stock in existence prior to the change. But what sense could be given to this thought experiment other than in exceptionally bold cases, such as the "corn model", where there is a single capital good, corn (used as seed), and where "more" or "less" of this capital good has an unambiguous meaning? But what is the meaning in the only interesting, because realistic, case in which there

\footnotetext{
5 Sraffa at the same time made clear that there was no harm in employing such an assumption -a counterfactual- in playing with what he occasionally called a "toy", i.e. the system of equations, provided we did not mistake the results obtained for what was going to happen in reality.
} 
are heterogeneous capital goods? How could the quantity of capital or its incremental increase be ascertained independently of relative prices and thus the rate of profits on whose magnitude the prices depend? This difficulty had not escaped the more attentive marginalist theorists, such as Knut Wicksell. ${ }^{6}$ Confronted with the problem they tried to cope with it as best as they could -eager to preserve, of course, the overall marginalist or demand and supply approach, which they considered to be the only one available. ${ }^{7}$ This made them abandon the concept of a physical concept of capital and put in its place a value concept. That is, they contemplated a marginal increase in the value of capital (in terms of some numéraire) employed and allowed for an optimal adjustment of the physical composition of the capital endowment to the other data of the economic system -preferences of consumers, technical alternatives available to producers, and the endowments of the economy of original factors of production (labour and land). ${ }^{8}$

Alas, this was not really a way out of the impasse, and it landed them right away in another difficulty. According to the received marginalist intuition (see above) which obtained its clue from the classical principle of intensive diminishing returns and thus the principle of intensive rent, the remuneration of a factor of production relative to the remunerations of other factors should be the smaller (larger), the smaller (larger) is its relative scarcity. In the case of an incremental increase of capital coeteris paribus, capital becomes relatively more abundant, i.e., relatively less scarce, and therefore its rate of remuneration -the rate of interest (or profits)-can be expected to fall, following the usual marginalist reasoning. This, however, implies that methods and entire techniques of production available at a given moment of time can be ordered monotonically in terms of the capital-labour ratio

\footnotetext{
${ }^{6}$ For a discussion of Wicksell's attempts to come to grips with the problem of capital in a marginalist context, see Kurz (2000a).

7 Their inability to see that there existed an earlier approach, i.e. that of the classical economists, reflects well Sraffa's observation that since the "advent of the 'marginal' method" the former had been "submerged and forgotten" (1960: v).

8 For a detailed discussion of this move, see Garegnani (2010); see also Kurz and Salvadori (1995, chapter 13).
} 
(or capital intensity) they represent with respect to the rate of interest. Sraffa's demonstration of the possibility of the reswitching of techniques and of reverse capital deepening showed that this view cannot generally be sustained: the marginalist theory of value and distribution was not the alleged general theory its advocates thought it was. ${ }^{9}$ It applied only in special circumstances on which more below.

We now turn to a brief discussion of the development of Sraffa's constructive, critical and interpretative work. The reader interested in a fuller account is asked to consult Kurz (2003), Garegnani (2005), Kurz and Salvadori (2005), Kurz (2006a) and Gehrke and Kurz (2006).

\section{The Route by Which SRAFFa ReACHEd his CONCLUSIONS}

According to Sraffa, in economics the conclusions are sometimes less interesting than the route by which they are reached. In his case, it is interesting to have a look both at the route he took and the conclusions at which he arrived.

\section{The coeteris paribus assumption}

In the mid 1920s Sraffa had criticized the Marshallian partial equilibrium analysis. He had shown that Marshall's theory was both logically inconsistent and could not explain the facts (Sraffa, 1925, 1926). Much of Sraffa's criticism concerned the coeteris paribus assumption, employed by Marshall. In his papers Sraffa often called it "stupid", because it is generally not possible to hypothetically change just one variable, such as the wage rate, and think of all others as "frozen in". ${ }^{10}$ Marshall's approach in terms of simple demand and supply schedules designed to determine the price and quantity of a thing

\footnotetext{
9 The phenomena under consideration were discussed in great detail during the so-called "Cambridge controversies in the theory of capital". The classic source for a summary account of the controversies is Harcourt (1972); see also Garegnani (1970) and Kurz and Salvadori (1995, chapter 14).

${ }^{10}$ For a consequent recognition of this fact in long-period theory, see Opocher and Steedman (2011). They show that many of the propositions of received demand and supply theory are untenable.
} 
traded cannot be sustained. Since marginal analysis in general procedes in terms of the coeteris paribus assumption (e.g., change the "quantity of capital", other things equal), it was clear that a central element of Sraffa's critical project had to consist in demonstrating the "stupidity" of this assumption by way of a general analysis. This he began to elaborate in the late 1920s in an attempt to lay bare, and then develop, the classical economists' approach to the theory of value and distribution.

\section{Equations without and with a surplus}

From November 1927 up until the end of the decade Sraffa had managed to establish in terms of what he called his "first" and "second equations" the mathematical properties of economic systems as regards income distribution and relative prices supporting any such distribution in the case of singleproduct industries and a given real (i.e. "inventory") wage rate without and with a social surplus. The attention focussed on the case of free competition and thus a uniform rate of profits. Sraffa was clear that in systems with a surplus the "scramble for the surplus" necessitates taking into account social institutions in addition to "natural" conditions of production and abandoning the concept of cost and prices as determined exclusively by the latter. He understood, and illustrated in terms of numerical examples, that relative prices generally depend on the sharing out of the surplus amongst workers and capitalists. He established an inverse relationship between the rate of profits and the share of wages, following Ricardo's concept of "proportional wages". It was thus not possible to assume an isolated change in the wage rate, for example, because such a change necessitated a change in the general rate of profits and relative prices, given the system of production. By 1929 Sraffa had fully solved the problem of extensive diminishing returns and thus extensive rent and had established (1) that the choice of which qualities of land to cultivate depends on the level of the wage rate and (2) that the order of rentability and the order of fertility of different qualities of land need not coincide. He even came close to stating the possibility of a particular quality of land being cost-minimizing (and 
thus profitable) at two different levels of the wage rate, with another quality of land being cost-minimizing at levels of the wage rate in between, i.e. the phenomenon of reswitching with regard to the use of lands. In the late 1920s he also began to study the problem of fixed capital.

\section{Reasoning in a circle}

By the early 1930s Sraffa had established the fact that neither the quantity of capital employed with a particular method of production nor the quantity of capital employed in a particular industry nor the capital employed in the economy as a whole could be ascertained independently of relative prices and the distribution of income. For a given real wage rate the general rate of profits and the prices of commodities (expressed in terms of some standard of value), and thus the value of capital, were determined simultaneously. The marginalist postulate of a given quantity of capital (whether relating to a method of production, an industry or the entire economy), whose marginal productivity would determine the profit rate, presupposes as already known what is yet to be ascertained: the rate of profits.

\section{Observer versus experimenter}

In a document composed in the summer or autumn of 1929 Sraffa compared the sets of given quantities used in different theories in order to determine value in given conditions (D3/12/13: 2-5). The quantities involved may be classed in three groups. The first group encompasses quantities

which cannot possibly be measured, because they are not defined in terms of the method of measuring them, e.g. marg.[inal] utility and sacrifice. (No definition at all is given for measuring them in the case of several individuals: in the case of one individual, they are defined as being proportional to certain quantities, i.e. prices, but this is, as Cairnes says, "merely giving a name to the unknown causes of price"). Such quantities must be excluded altogether: at the worst, they may be used as a fictitious device for solving problems, but must not appear either in the premises nor in the conclusions. 


\section{About the second group Sraffa wrote:}

At the opposite extreme there are quantities which can be, and in fact are, statistically measured. These quantities have an objective, independent existence at every or some instants of the natural (i.e. not interfered with by the experimenter) process of production and distribution; they can therefore be measured physically, with the ordinary instruments for measuring number, weight, time, etc. Such are quantities of various materials used or produced, of lands, quantities of labour (?), lengths of periods (?), etc. $\left.{ }^{11}\right]$ These are the only quantities which must enter as constants in economic theory, i.e. which can be assumed to be "known" or "given".

To this Sraffa added: “'The 'extensive' theory of rent, and the labour theory of value only assume this kind of knowledge." 12 Notice also his reference to the "experimenter" who, differently from the detached "objective" observer, is said to interfere in the process, thereby changing its properties. This distinction plays a crucial role in his argument. Its meaning becomes clear when we turn to the third group:

Finally, there is the class of quantities, which form the basis of Marshall's theory (or, rather, of Pareto's), such as demand and supply curves, marginal productivities (i.e. rate of growth of total), indifference curves, etc. Here the constant quantities have no names - they are the parameters of curves. The several quantities represented by these curves do not exist at any one moment, nor during any period of the recurrent steady process of production or consumption. They are alternatives, only one of which can exist in any one position of equilibrium, all the others being thereby excluded (even the one does not really exist if there is no change, since it is the rate of growth of a quantity, i.e. marginal product: it can be inferred from price, but so can marginal utility, which [...] we have agreed does not exist). Therefore, they cannot be found by merely observing the process or state of things, and measuring the quantities seen. They can only be found out by means of experiments

${ }^{11}$ At the time Sraffa still vacillated as to whether the magnitudes with a question mark in brackets could in fact be treated as constants. See on this Kurz and Salvadori (2005, section 3).

12 This does not mean that Sraffa was uncritical of the labour theory of value, it only means that contrary to the marginalist theory it starts from the same set of data, or independent variables, or given quantities as Sraffa's own approach. For a discussion of Sraffa's (changing) views on the labour theory of value, see Kurz and Salvadori (2010b). 
-and these quantities in effect are always defined in terms of such experiments (successive doses applied to land; alternatives offered to the consumer; etc.).

He continued:

These experiments cannot be carried out (and never have been, as a matter of fact) for various reasons: 1) the practical difficulties, 2) the lack of definition of the conditions to be required, which are always summed up in the absurd "other things being equal["].

But even apart from these difficulties, which might conceivably be overcome, there remains something about these experiment[s] which is very curious: they are generally regarded as acceptable, as if they were calculated to reproduce under controlled conditions, so as to be able to measure them, facts which actually happen "in nature" all the time but cannot directly be pinned down by observation. But the experiments have an entirely different significance: they actually produce facts which would otherwise not happen at all; if the experimenter did not step in first to produce them, and then to ascertain them, they would remain in the state of "unknown possibilities", which amounts to the deepest inexistence. (Sraffa Papers, D3/12/13: 2-5; Sraffa's emphases).

Marginalist theory, Sraffa insists, does not simply analyse a given system as it is, it rather presupposes a somewhat different system. It does not accept the facts as they are, but first produces new "facts". Counterfactuals of a very particular kind are a sine qua non in marginalist theory right from the beginning: without them there would be no theory. Counterfactuals in classical theory play a very different role: they exemplify what the theory, which has been elaborated without any reference to counterfactuals, has to say in case some of the quantities of the second kind change. ${ }^{13}$

\section{"Bortkiewicz's dictum" and the "monotonic prejudice"}

In 1931 Sraffa had to abandon the project of reconstructing the classical approach in favour of the "big Ricardo", the editorial project with which

${ }^{13}$ For a more detailed discussion of the role of counterfactuals in alternative theories, see Kurz (2006b). 
the Royal Economic Society had entrusted him in 1930. Soon after he was finally able to resume his work on the first project in 1942 (he had to abandon it again because of the Ricardo edition in 1946 after the discovery of the correspondence of Ricardo with James Mill) he in the following year by accident came across Ladislaus von Bortkiewicz's essay in three parts "Wertrechnung und Preisrechnung im Marxschen System" (1906-7) and then studied other contributions by the same author. These served him as a welcome litmus paper test of his own earlier findings in the theory of value and distribution and the knowledge he in the meantime had accumulated on the classical authors and Marx. It can have only increased his interest in Bortkiewicz's papers when Sraffa discovered that the Berlin professor had enunciated essentially the same maxims the theory of value and distribution was supposed to meet as he, Sraffa, had done in the first period of his constructive work. Methodologically, Bortkiewicz was thus seen as a comrade in arms, although Sraffa was highly critical of some of the latter's views (see Gehrke and Kurz, 2006). In particular, Bortkiewicz had put forward what Sraffa called "Bortkiewicz's dictum" or "dogma". Against Böhm-Bawerk's theory of interest (profit) Bortkiewicz had insisted:

I believe that this can be regarded as the touchstone of such a theory: whether it is able to show the general cause of interest also for the case in which not only no technical progress, of whichever type, takes place, but also the length of the periods of production appears to be technically predetermined, so that no choice is possible between different methods (Bortkiewicz, 1906: 970-1; emphasis added)..$^{14}$

In other words, interest was to be explained in conditions of a given system of production -setting aside both a choice of technique and technical progress. In another paper Bortkiewicz had added the following specification of his maxim:

14 To the above passage Bortkiewicz had appended a footnote in which he stressed that also J.B. Clark's theory of marginal productivity does not satisfy this requirement. 
Now my opinion is that in general the value of goods can only depend upon such technical knowledge as is applied in practice. But the value of goods remains unaffected by knowledge, which, on whatever grounds, is not utilized.

The result thus obtained can be summed up in the following brief formula: for [the determination of] the value of goods there come into consideration only actual methods of production (Verwendungsarten), and not merely potential ones. (D1/91: 7; see Bortkiewicz, 1907: 1296-7 and 1299).

Sraffa marked these passages approvingly in the margin. In fact, without knowing Bortkiewicz's work, Sraffa in his systems of equations in the late 1920s had strictly adhered to the dictum, which flew in the face of the marginalist approach.

Sraffa was however critical of Bortkiewicz's opinion that techniques could generally be ordered monotonically in the usual marginalist way. As Sraffa noted, Bortkiewicz had correctly pointed out, against BöhmBawerk, that there is "no 'average period of production" which could be defined independently of the rate of interest but then had nevertheless put forward the erroneous proposition that "in general" there is a lengthening of the period (i.e. an increase in capital intensity) with a fall in the rate of interest. This unwarranted belief reflected what Sraffa called a "monotonic prejudice" (Sraffa Papers, D1/91: 14 and 27, verso). In fact, he had criticized this view as early as February 1931, and in his working notes he had in fact demonstrated the impossibility of a general monotonic ordering of the methods of production long before he came across Bortkiewicz's essay. In one of his notes, commenting on Kaldor (1939), another economist who had fallen victim to the prejudice, for example, he had pointed out:

There is no assurance that, owing simply to a change in the rate of interest, the order is not reversed. Suppose two commodities produced by similar proportions of capital and labour (i.e. which are similarly divided between profits and wages): but one contains more capital in the "early" stages and less in the later ones -i.e. although the total quantity of interest is equal in the two commodities, in this one it is made up to a larger extent of compound interest: it is clear that if the rate of profits rises, the composition of this commodity will come to contain more profits (i.e. capital) than the other (Sraffa Papers, D3/12/15: 10). 
Hence a main pillar upon which marginalist theory rested, the principle of substitution in production, could not be relied upon. ${ }^{15}$ Alternative methods of production to produce a particular economy and even entire systems of production cannot generally be ordered monotonically in terms of the capital-output ratio (or the capital-labour ratio) with regard to the rate of interest (profits).

\section{The "surrogate production function" and its defects ante litteram}

Sraffa also pointed out in which exceptional circumstances the marginalist theory applies. It turned out that these circumstances were the same that guaranteed a strict proportionality between relative prices and the amounts of labour expended in the production of the various commodities, i.e. a situation in which the simple (or rather debased) labour theory of value holds true. ${ }^{16}$ Interestingly, in a note composed on 16 January 1946 Sraffa anticipated the flaw besetting Samuelson's 1962 attempted defense of the received long-period marginalist theory in terms of the concept of the "surrogate production function" (Samuelson, 1962). As Sraffa's argument makes clear, Samuelson's reasoning sixteen years later had no claim to general validity. On the contrary, it presupposed the validity of the simple labour theory of value and thus held strictly true only in a one-good economy:

The Irony of it is, that if the "Labour Theory of Value" applied exactly throughout, then, and only then, would the "marginal product of capital" theory work!

15 Bliss (2010: 636) writes that Sraffa "allows no substitution within a single process." Apparently Bliss defines processes as including entire substitutive production functions. In Sraffa's analysis there is of course "substitution" among factors via a change in the methods of production adopted at different levels of the wage rate (or the rate of interest). However, there is no presumption that this kind of substitution supports the monotonic prejudice: "ratio of interest rate-to-wage rate up, ratio of capital-to-labour down”.

${ }^{16}$ Neither Ricardo nor Marx had advocated such a theory. They understood perfectly well that in "time-phased" conditions (to use an expression Paul Samuelson coined) relative prices depend not only on the absolute amounts of labour quantities, but also on the time profiles of their expenditure and thus on the level of the wage rate (or the level of the rate of profits). 
It would require that all products had the same org.[anic] comp.[osition]; and that at each value of $r$, each comm. [odity] had an "alternative method", and that the relations within each pair should be the same (i.e. that marg.[inal] prod[uct]s. should be the same; $[\ldots])$; so that, even when the System is switched, and another Org. Comp. came into being, it should be the same for all products.

Obviously this would be equivalent to having only one means-product (wheat). Then, commodities would always be exchanged at their Values; and their relative Values would not change, even when productivity of labor [sic] increased (Sraffa Papers, D3/12/16: 34, emphasis is in original). ${ }^{17}$

Sraffa's careful scrutiny of the marginalist theory of value and distribution thus led him essentially to the same conclusion he had reached with respect to Marshall's theory: "the theory cannot be interpreted in a way which makes it logically self-consistent and, at the same time, reconciles it with the facts it sets out to explain" (Sraffa, 1930: 93).

This brief summary account of some of Sraffa's objections to the marginalist concept of capital does not, of course, exhaust his critique of marginalist theory or rather of the various versions in which it existed. Sraffa perused carefully the contributions of, among others, Jevons, Walras, John Bates Clark, Böhm-Bawerk, Cassel, Wicksell, Pareto, Lindahl and Hicks and jotted down his critical observations. ${ }^{18}$ Due to space constraints it must suffice to draw the readers' attention to just a few of them.

\section{"Men kick"}

Sraffa insisted that the demand and supply schedules have no objective contents: nothing corresponds to them in the real world. Especially in his earlier papers he repeatedly pointed out that the working horse of marginalist theory, the isolated utility maximizing agent - homo oeconomicus- is seriously misleading. In an undated passage (which, however, was in all probability

\footnotetext{
${ }^{17}$ The parts in italic are underlined in the original.

18 The reader must not think that Sraffa's critical attitude was limited to marginalist authors: he read each and every author with great attention and pointed out shortcomings of the argument, whenever he discerned them. Ricardo, Marx or Keynes were no exception to the rule.
} 
written in 1942) he counterposed his own physical real cost approach (pertaining to systems with a given real wage rate) and the marginal utility approach and stressed that in his 1 st and 2 nd equations the "food and sustenance of the workers [are] treated [...] on the same footing as that of horses." He added with characteristic irony: "Men however (and in this they are distinguished from horses) kick." This is, of course, an allusion to the "scramble for the surplus", which fixes the real wage rate and which is decided according to the particular circumstances ruling at a given place and time. ${ }^{19}$ As to the special nature of horses, which is fundamentally different from the nature of men, Sraffa explained: "The horse (or his physiology) takes a strictly private view of his relation with his food [...]: he is a perfect utilitarian and thus forms the ideal object of study of the marg.[inal] utility economist" (Sraffa Papers, D3/12/16: 18).

\section{Supply and demand not independent of one another}

Sraffa disputed the marginalist view that production and consumption, or "supply" and "demand", can be envisaged as entirely independent from one another. He quoted approvingly from a paper by John Maurice Clark (1918: 8; emphasis added):

Economic wants for particular objects are manufactured out of this simple and elemental raw material [primitive instincts] just as truly as rubber heels, tennis balls, fountain pens, and automobile tires are manufactured out of the same

19 As the context in which Sraffa speaks of the "scramble for the surplus" (Sraffa Papers, D3/12/11: 83) makes clear, the reference is to Adam Smith's discussion of the conflict over the distribution of income between "workmen" and "masters" in chapter VIII of book I of The Wealth of Nations (1976, WN, I.viii). Smith stressed: "What are the common wages of labour, depends every where upon the contract usually made between those two parties, whose interests are by no means the same. The workmen desire to get as much, the masters to give as little as possible. The former are disposed to combine in order to raise, the latter in order to lower the wages of labour." (WN, I.iii.11) However, due to differences in the size of each "party" (an argument that draws the attention to the problem of collective choice and action) and institutional factors he saw the masters to have commonly "the advantage in the dispute, and force the other into a compliance with their terms” (WN, I.viii.12). 
crude rubber. The wheels of industry grind out both kinds of products. In a single business establishment one department furnishes the desires which the other departments are to satisffy ${ }^{20}$ (Sraffa Papers, D3/12/7: 4-8, Sraffa's emphasis).

If demand and supply functions are not independent of one another, what is the explanatory value of a theory that depends on their independence?

\section{Externalities}

As regards the ubiquitous problem of externalities, Sraffa pointed out that "it is not sufficient to make utility of one commodity a function of all others consumed by the individual", as in Vilfredo Pareto's general equilibrium analysis, but it had also to be made dependent on the consumption of the "community" as a whole. Alas, "It would be as if in astronomy we said the movement of each star depends upon all the others, but we have not the faintest idea of the shape of the functions!" (Sraffa Papers, D3/12/3: 70) Surely, this was the problem, and the received marginalist theory, rooted in methodological individualism, could not possibly deal with it. The classical approach right from the beginning focuses attention instead on certain properties of the economic system as a whole, that is, those relating to income distribution and relative prices in conditions of free competition. Its advocates identified the relationships of the conflicting interests and claims of different groups or classes of agents to the social product -workers, capitalists and land owners- that are compatible with the given system of production. Any theory starting from the volitions, decisions and behaviour of people would have to respect such properties and relationships and would have to come up with the same type of equations and solutions Sraffa had elaborated (and actually did come up with those equations, as, for example Léon Walras: see Kurz and Salvadori, 1995: 22-5). Sraffa's argument was designed to show that the "forces" contemplated by marginalist theory,

\footnotetext{
${ }^{20}$ In the margin of the last two sentences Sraffa put two straight lines, signalling agreement with the view stated in the text.
} 
utility and disutility, reflected in demand and supply schedules, could not accomplish the task, whether it be for reasons of a lack of logical selfconsistency of the argument or for an inability to reconcile the argument with the facts it sets out to explain.

\section{IMPLICATIONS FOR A THEORY OF EMPLOYMENT, OUTPUT AS A WHOLE AND ECONOMIC GROWTH}

From what we have just learned follow certain implications for the main problem Keynes was concerned with, that is, the explanation of employment and output as a whole, and also for the relationship between Sraffa's work and the works of Keynes and some Post-Keynesians. In order to get a clearer idea of this relationship we take into consideration other aspects of Sraffa's writings. ${ }^{21}$

\section{Say's law cannot be sustained}

The most important conclusion that follows from Sraffa's investigation of the problem of the choice of technique is that Say's law of markets (as envisaged by the marginalist authors) cannot be sustained. ${ }^{22}$ If we cannot rely upon the

\footnotetext{
${ }^{21}$ See also Petri (2004), who draws out the implications of Sraffa's work for general equilibrium theory and macroeconomics.

${ }^{22}$ While in the marginalist conceptualization of the "law" the idea of a permanent tendency to market clearing concerns also the labour market, things are different in the classical authors. As no less an authority than David Ricardo put it in his Principles of 1817: "There is no amount of capital [!] which may not be employed in a country, because demand is only limited by production" (Ricardo, 1951: 290, emphasis added; see also Gehrke and Kurz, 2001). Notice that the reference is to the employment of capital, not labour, and to production, not employment. The classical authors envisaged Say's law to apply only to commodities, whose production is motivated by expected profits. Since labour, although a particular kind of commodity, cannot be subsumed under this motive, Say's law was not applicable. It was only with the wage fund doctrine and then in marginalist analysis that the "law of markets" was generalized to include a labour market: with flexible prices and wages and sufficient substitutability between goods in consumption and factors in production, all markets, including the market for labour, were taken to clear. Hence the "forces" of demand and supply were seen to establish a tendency towards the full employment of labour and the full utilization of plant and equipment.
} 
principle of substitution in production expressing the monotonic prejudice, then there is no reason to presume that the economy, if left to itself, will bring about a tendency towards the full employment of all productive factors. This result does not depend on the (downward) stickiness of prices as it is assumed, for example, in Neo-Keynesian models (but not in Keynes or the Post-Keynesians). Even if prices were flexible, a fall in the real wage rate need not bring about rising levels of employment, as conventional economic theory predicts. Prices in the classical economists and Sraffa play a different role from the one they play in the marginalist authors. According to Smith and Ricardo, normal or "natural" prices are not scarcity indexes and thus do not perform the task of guiding the economy towards full employment. Prices rather reflect the balance of power in the struggle over the distribution of income in given historical and institutional circumstances. Income distribution is not explained with reference to the demand for and the supply of productive factors. There is also no explanation of distribution in terms of marginal productivities of the respective factors. Profits (and rents) are a residual income that obtains within a given system of production and given real wages (or a given share of wages).

Both Keynes and Sraffa rejected Say's law, although for different reasons. With the analysis not constrained by the straightjacket of the full employment assumption, we do not encounter in classical economics such concepts as Pareto optimality: a system which, in normal conditions, exhibits smaller or larger margins of unused productive capacity and work force is subject to different laws than a system characterized by full employment and full capacity utilization. In conditions with idle productive capacity the usual marginalist reasoning does not apply. In the marginalist world effective aggregate demand, by definition, has no impact on actual output and its growth over time, whereas in the world of the classical economists it has.

\section{Effective demand matters both in the short and in the long run}

A peculiarity of demand constrained systems is that over longer periods of time excess capacity does not become fully visible and we might easily 
fall victim to the illusion that the capital stock is always more or less fully utilized. As regards labour, we are familiar with the phenomenon that the longer workers are without jobs the more difficult it is for them to get reintegrated into the employment system, because being on the dole is accompanied by a gradual loss of skills and the capability to work. As regards capital, any underutilization implies a smaller social product than possible, therefore a smaller rate of formation of fresh capital, therefore a smaller rate of growth of the social product etc. (see Garegnani, 1978, 1979). Hence, a level of effective demand that falls short of productive capacity for some time is reflected in the short run by an underutilization of given productive capacity and in the long run by a smaller pace at which productive capacity grows. While the labour force will be diminished as a consequence of unemployment caused by effective demand failures, the capital stock will expand less swiftly. In both cases the full effects of sustained insufficient effective demand are concealed. The inattentive observer might actually conclude that in the long run the system can be assumed to operate in conditions of close to full employment of labour and close to full capital utilization, whereas what actually happens is that effective demand slows down the development of the supply side of the economy. It would be an elementary mistake to think that the supply side can be studied without taking into account the role of aggregate effective demand in shaping it.

In assuming full employment of labour and full capacity utilization, neoclassical models, old and new, follow Robert Solow's and Trevor Swan's example who in their 1956 contributions explicitly set aside problems of effective demand and assumed what Solow called a "tight rope view of economic growth". However, we ought to add to their credit that Solow and Swan were not of the opinion that there are no such problems, both in the short and in the long run; see recently Solow's preface in Aghion and Durlauf (2005: 5). Despite his warnings, modern neoclassical growth theorists, especially Robert Lucas, continued to be concerned almost exclusively with the evolution of potential output and ignore all effective demand failures. Interestingly, the subject index of the Handbook of Economic 
Growth, edited by Aghion and Durlauf, has no entry on capacity or capital utilization. Ignoring the demand side is justified by Lucas and his followers or surrogates in terms of the overwhelming importance of long-run growth compared with short-run fluctuations. These authors are not exempt from the illusion mentioned above. Assume two identical economies except for the fact that one, due to a better stabilization policy, manages to realize on average, over a succession of booms and slumps, a higher average rate of capacity utilization than the other economy. With $Y$ as actual and $Y^{*}$ as capacity (or potential) output, $s$ as the savings rate, $v$ as the actual and $v^{*}$ as the optimal output-to-capital ratio and $u=Y / Y^{*}$ as the average degree of utilization of productive capacity, we have

$$
g_{i}=\frac{S}{Y} \cdot \frac{Y}{K}=\frac{S}{v}=\frac{S}{Y} \cdot \frac{Y^{*}}{K} \cdot \frac{Y}{Y^{*}}=\frac{S}{v^{*}} u_{i},(i=1,2)
$$

Assume now that $s=0.2$ and $v^{*}=2$, but $u_{1}=0.8$ and $u_{2}=0.7$. Then the first economy would grow at eight per cent per year, whereas the second would grow at only seven per cent. This may seem a trifling matter, and in the short run it surely is, but according to the compound interest formula after about 70 years the first economy would be larger than the second one by the amount of their (common) size at the beginning of our consideration. ${ }^{23}$ Hence effective demand matters. Experience also suggests that there is no reason to presume that actual saving can be expected to move sufficiently close around full employment and full capacity saving. Persistently high rates of unemployment in many countries, both developed and less developed, strongly indicate that the problems of growth and development cannot adequately be dealt with in terms of the full employment assumption.

\footnotetext{
${ }^{23}$ This argument sets aside all effects which different activity levels of the economy might have on its overall propensity and capability to innovate and thus increase productivity.
} 


\section{Criticism of received marginalist views}

For obvious reasons Sraffa also did not share the following marginalist doctrines, which are, of course, nothing but aspects or implications of the theory itself. He rejected in particular

- the concept of an investment function according to which the volume of investment in the economy is elastic with respect to the level of the money rate of interest;

- the view that an increase in saving spurs economic growth;

- the idea that the supply of money can be regulated by the monetary authority with sufficient precision, i.e. that the quantity of money in the system is exogenous;

- the contention that economic policy is ineffective in the sense that fiscal and monetary policies can have no lasting impact on the performance of the economy.

\section{Investment demand}

The postulated inverse relationship between the volume of investment and the rate of interest is but another expression of the monotonic prejudice and cannot generally be sustained for the reasons given in the above. Alas, Keynes adopted a version of this concept in terms of his "marginal efficiency of capital" schedule. ${ }^{24}$ He rests his argument on the dubious partial equilibrium method. Yet the schedule and the money rate of interest cannot be assumed to be independent of one another (see Kurz, 2010: 192-4). Several commentators (e.g. Pasinetti, 1974) have pointed out that Keynes's argument consists of an adaptation of the classical doctrine of extensive diminishing returns to the theory of capital and investment. Accordingly, different investment projects can be brought into an order of profitability in a similar way as different qualities of land can be brought into an order of fertility: the different investment projects will be realized according to the first order in a similar way as the different qualities of land will be taken

\footnotetext{
${ }^{24}$ As regards the long period, Keynes (1936: 136) advocated the view that an increase in the capitallabour ratio is invariably accompanied by a decrease in the marginal efficiency of capital in general, which expresses, of course, the conventional marginalist viewpoint.
} 
into cultivation according to the second one. Sraffa's demonstration in the late 1920s that the order of fertility generally depends on the rate of interest undermines both concepts. As regards the problem of the use of land, Sraffa, when resuming his work in 1942, asked: "Is it possible in our scheme to arrange a series of lands of different qualities in a descending order of 'fertility' that will be valid for all values of (independently of) $r$ and $w$ ? No, it is not possible." (Sraffa, Papers D3/12/25: 1)

\section{Paradox of thrift}

The idea that any act of saving will entail an act of investment of the same magnitude is, of course, the core proposition of Say's law. Both Keynes and Sraffa rejected Say's law and thus also the view that an increase in saving necessarily leads to an increase in investment. The "paradox of thrift" implies on the contrary that because of its negative effect on aggregate effective demand and capital utilization, an increase in saving may in certain circumstances frustrate investors. The shrinking volume of investment will exacerbate the problem of effective demand and send the economy into a downward spiral, as analysed by Roy Harrod with his "Instability Principle" (see Harcourt, 2006, chapter 7). Both Keynes and Sraffa were convinced that with respect to the performance of the economic system as a whole the attention should focus first and foremost on investment and not on saving (and consumption), because investment generates the amount of savings via changing levels of output and capital utilization (short run) or changing rates of expansion of productive capacity (long run).

\section{Effective demand and obsolete machines}

Before we turn to the next issue, the reader's attention should be directed to an aspect of Sraffa's system of equations which has been overlooked by many commentators, and which indicates clearly that the equations can deal with different levels of effective demand. In the last section of the chapter devoted to land, Sraffa mentions "obsolete machines" and stresses: 
Machines of an obsolete type which are still in use are similar to land in so far as they are employed as means of production, although not currently produced. The quasi-rent (if we may apply Marshall's term in a more restricted sense than he gave it) which is received for those fixed capital items which, having been in active use in the past, have now been superseded but are worth employing for what they can get, is determined precisely in the same way as the rent of land. (Sraffa, 1960: 78).

The larger is the effective demand for the various commodities, the more of these obsolete machines will have to be used, and their use is possible provided the needed additional workforce is available, i.e. there is unemployment, which Sraffa implicitly assumes to be the case. ${ }^{25}$

\section{Endogenous money}

As regards the role of money and the control of its quantity, we should recall that Sraffa started as a monetary economist and throughout his life had a vivid interest in monetary issues, institutions etc. When at the beginning of the 1930s Friedrich August von Hayek launched an attack on Keynes's Treatise on Money (Keynes, 1930), Keynes found himself in an impasse because he was not familiar with the main building blocks of Hayek's criticism: Böhm-Bawerk's theory of capital, Pareto's theory of general equilibrium and Ludwig von Mises's views on money. He wisely asked Sraffa, who was familiar with the works of the authors mentioned, to come to his defense. Sraffa did so in terms of a counter-attack on Hayek's Prices and Production (Hayek, 1931), to which Hayek replied and Sraffa responded.

Here is not the place to enter into a detailed discussion of this debate; see therefore the accounts provided in Kurz (2000b and 2010: 194-7). It suffices to point out two things. First, from Sraffa's argument it follows that while the banking system can fix the rate(s) of interest, the amount of money in the system is endogenous. To assume a coeteris paribus change in the rate of interest is once again not admissible. Secondly, in his debate with

${ }^{25}$ For a formalisation of the case of obsolete machines in Sraffa, see Kurz and Salvadori (1995: 348-51). 
Hayek, Sraffa introduced the concept of a "commodity rate of interest". This concept Keynes was eager to pick up in the General Theory (Keynes, 1936, chapter 17, especially 223n.), because he thought that it would provide him with the long sought choice- and capital-theoretic foundation of his theory of investment behaviour, both real and financial. The lack of such a foundation was a major objection Hayek had put forward against the Treatise. The new concept allowed Keynes, or so he thought, to drive home the main message of the General Theory, that it is the downward rigidity of the money rate of interest that is the source of all the trouble. This downward rigidity is in turn explained in terms of the liquidity preference of wealth owners.

\section{“Keynes's system" -liquidity preference theory}

Sraffa was not at all happy with Keynes's use of the concept of commodity rates of interest and he was critical of his explanation of why liquidity preference was to prevent the money rate of interest from falling sufficiently not only in the short, but also in the long run (see Kurz, 2010). In Sraffa's view, as it is expressed both in his annotations of his personal copy of the General Theory and in two manuscript fragments, Keynes's argument was a mess, confused and confusing. He argued, among other things, that the concept of liquidity that Keynes uses, is vague and ambiguous; that there is no reason to presume that liquidity is always a good thing for each and every type of agent -in fact, the downward sloping liquidity preference curve is but a variant of the usual marginal utility curve; and that Keynes inconsistently admitted Fisher's effect for all commodities, except money. The last objection refers to a situation where because of the depressive tendencies in the economy money prices will tend to fall, that is, the value of money will rise. However, an expected rise in the value of money implies a lower "own rate of money interest", and not a higher one, as Keynes had assumed. In chapter 17, Sraffa concluded, Keynes did not reason correctly and got entangled in a maze of contradictions. Keynes's liquidity preference theory -which Sraffa called "Keynes's system"- could not bear the brunt of the explanation of a downward rigidity of the interest rate. Yet if the interest 
rate was flexible and if investment was sufficiently elastic with respect to the rate of interest, then there was no reason to presume that investment could not gravitate towards a level equal to full employment saving.

In short, the "revolutionary" message of Keynes's book was thwarted not so much by Keynes's occasional sloppiness, but by his retaining in new garb marginalist concepts that Sraffa considered to be untenable. Seen in this way, Keynes was not completely successful in what he had called a "struggle of escape from habitual modes of thought and expression" (Keynes, 1936: xxiii). Sraffa approved of Keynes's critical intention, but was disenchanted with its execution. In important respects he felt that Keynes had granted too much to received economic theory. Keynes's new theory exhibited several loose ends and contradictions and retained marginalist concepts.

It is ironic to see that the distinguishing feature of what today is known as "Neo-Keynesian" and "New-Keynesian theory" is the premise of sticky prices: Keynes is interpreted as an imperfectionist. While there are traces of imperfectionism to be found in his magnum opus, in the central part of it he assumes fully flexible prices. Keynes's analysis therefore cannot be accused of lacking generality because of an alleged assumption of price rigidities. The problem rather is whether his explanation of a lower boundary to the money rate of interest (in combination with an inverse investment-interest relation) vis-à-vis flexible prices stands up to close examination. According to Sraffa it does not. Keynes's argument suffers in particular from neglecting the implications of flexible prices via the value of money for the level of the "own rate of money interest". However, Keynes's failure must not be taken to be orthodox theory's triumph. In Sraffa's view, Keynes failed because in his analysis the orthodox elements overwhelm the truly novel ones.

Sraffa developed his criticism of Keynes from an approach that also considers (long-period) prices as fully flexible. This does not mean, however, that the conventionally invoked "forces of demand and supply" can be expected to generally bring about a full employment equilibrium. The irony is that Sraffa established these findings in terms of an elaboration of the classical approach to the theory of value and distribution. This approach, coherently developed, actually effectively undermines Say's law -the law for which Keynes had thought he could put classical analysis on one side. 


\section{CONCLUding REMARK}

The principle of effective demand (Keynes) matters, in the long run no less than in the short run. Economics may be a dismal science or discipline (Carlyle), but the present dismal state of important parts of it applies not to the discipline as a whole or to all traditions of economic thought available. It applies to the neoclassical mainstream and especially to what is misleadingly called New Classical Economics. It does not apply to some other lines of economic thought, which, to the detriment of the discipline and even more so to the detriment of society, have been marginalized in the recent past. Severe economic crises request the economics profession to reconsider its doctrines, abandon views that can no longer be sustained, return to views that can, or create new ones appropriate to the current situation. As Keynes put it succinctly in the Tract on Monetary Reform: "Economists set themselves too easy, too useless a task if in tempestuous seasons they can only tell us that when the storm is long past the ocean is flat again."

\section{REFERENCES}

Aghion, P. and Durlauf, S.N. eds., 2005. Handbook of Economic Growth. Two vols, Amsterdam: Elsevier.

Bliss, C., 2010. The Cambridge Post-Keynesians: An outsider's insider view. History of Political Economy, 42(4), pp. 631-52.

Bortkiewicz, L.v., 1906-7. Wertrechnung und Preisrechnung im Marxschen System. Archiv für Sozialwissenschaft und Sozialpolitik, (1906) 23, pp. 1-50, (1907) 25, pp. 10-51 and 445-88.

Bortkiewicz, L.v., 1906. Der Kardinalfehler der Böhm-Bawerkschen Zinstheorie. Schmollers Jahrbuch, 30, pp. 943-72.

Bortkiewicz, L.v., 1907. Zur Zinstheorie. II. Entgegnung (reply to H. Oswalt). Schmollers Jahrbuch, 31, pp. 1288-307.

Clark, J.M., 1918. Economics and modern psychology. Journal of Political Economy, 26(1), pp. 1-30.

Garegnani, P., 1970. Heterogenous capital, the production function and the theory of distribution. Review of Economic Studies, 37, pp. 407-36. 
Garegnani, P., 1978. Notes on consumption, investment, and effective demand: I. Cambridge Journal of Economics, 2, pp. 325-53.

Garegnani, P., 1979. Notes on consumption, investment, and effective demand: II. Cambridge Journal of Economics, 3, pp. 63-82.

Garegnani, P., 2005. On a turning point in Sraffa's theoretical and interpretative position in the late 1920s, European Journal of the History of Economic Thought, 12(3), pp. 453-92.

Garegnani, P., 2010. On the present state of the capital controversy [manuscript]. Rome.

Gehrke, C. and Kurz, H.D., 2001. Say and Ricardo on value and distribution. The European Journal of the History of Economic Thought, 8, pp. 449-86.

Gehrke, C. and Kurz, H.D., 2006. Sraffa on von Bortkiewicz. Reconstructing the Classical theory of value and distribution. History of Political Economy, 38, pp. 91-149.

Hamouda, O. and Harcourt, G.C., 1988. Post-Keynesianism: from criticism to coherence? Bulletin of Economic Research, pp. 1-33.

Harcourt, G.C., 1972. Some Cambridge Controversies in the Theory of Capital. Cambridge: Cambridge University Press.

Harcourt, G.C., 2006. The Structure of Post-Keynesian Economics. Cambridge: Cambridge University Press.

Harcourt, G.C. ed., 2012. Handbook of Post-Keynesian Economics, three vols. Cheltenham: Edward Elgar.

Hayec, F.A., 1931. Prices and Production. London: George Routledge.

Kaldor, N., 1939. Capital intensity and the trade cycle. Economica, New Series, 6, pp. 40-66.

Keynes, J.M., 1930. A Treatise on Money. Two vols. London: Macmillan.

Keynes, J.M., [1936]. The General Theory of Employment, Interest and Money. London: Macmillan (Reprinted in Moggridge, D. ed., 1973. The Collected Writings of John Maynard Keynes, vol. VII. London: Macmillan).

Kurz, H.D., 2000a. Wicksell and the problem of the "missing equation". History of Political Economy, 32, pp. 765-88.

Kurz, H.D., 2000b. The Hayek-Keynes-Sraffa controversy reconsidered. In: Kurz, H.D. ed. Critical Essays on Piero Sraffa's Legacy in Economics. Cambridge: Cambridge University Press, pp. 257-301.

Kurz, H.D., 2003. The surplus interpretation of the Classical economists. In: Biddle, J.E., Davis, J.B. and Samuels, W.E. eds. The Blackwell Companion to the History of Economic Thought. Oxford: Blackwell, pp. 167-183. 
Kurz, H.D., 2006a. The agents of production are the commodities themselves. On the Classical theory of value and distribution. Structural Change and Economic Dynamics, 17, pp. 1-26.

Kurz, H.D., 2006b. On the use of counterfactuals in alternative theories of value and distribution [manuscript]. Graz.

Kurz, H.D., 2010. Keynes, Sraffa, and the latter's "secret scepticism". In Bateman, B., Hirai, T. and Marcuzzo M.C. eds. The Return to Keynes, Cambridge, MA, and London: The Belknap Press of Harvard University Press, pp. 184-204.

Kurz, H.D. and Salvadori, N., 1995. Theory of Production. Cambridge: Cambridge University Press.

Kurz, H.D. and Salvadori, N., 2005. Representing the production and circulation of commodities in material terms: On Sraffa's objectivism. Review of Political Economy, 17, pp. 413-41.

Kurz, H.D. and Salvadori, N., 2010a. The post-Keynesian theories of growth and distribution: a survey. In M. Setterfield ed. Handbook of Alternative Theories of Economic Growth. Cheltenham: Edward Elgar, pp. 95-107.

Kurz, H.D. and Salvadori, N., 2010b. Sraffa and the labour theory of value. In Vint, J. et al. eds. Economic Theory and Economic Thought. Festschrift in Honour of Ian Steedman. London: Routledge, pp. 187-213.

Lavoie, M., 2010. Post-Keynesianism. In Faccarello, G. and Kurz, H.D. eds. Handbook of the History of Economic Thought, vol. 2: Schools of Thought in Economics [forthcoming]. Cheltenham: Edward Elgar,.

Opocher, A. and Steedman, I., 2011. Full Industry Equilibrium. A Theory of the Industrial Long Run [partial version, manuscript]. Padova and Manchester.

Pasinetti, L.L., 1974. Growth and Income Distribution: Essays in Economic Theory. Cambridge, MA: мІт Press.

Petri, F., 2004. General Equilibrium, Capital and Macroeconomics. A Key to Recent Controversies in Equilibrium Theory. Cheltenham: Edward Elgar.

Ricardo, D., 1951. On the Principles of Political Economy and Taxation. [1st edition 1817]. Edited by Piero Sraffa with the collaboration of Maurice H. Dobb. Cambridge: Cambridge University Press.

Samuelson, P.A., 1962. Parable and realism in capital theory: the surrogate production function. Review of Economic Studies, 29, pp. 193-206.

Smith, A., 1976. An Inquiry into the Nature and Causes of the Wealth of Nations. [1st edition 1776] Campbell, R.H., Skinner, A.S. and Todd, W.B. eds. The Glasgow 
Edition of the Works and Correspondence of Adam Smith, vol. II. Oxford: Oxford University Press. (In the text quoted as WN, book number, chapter number, section number, paragraph number).

Sraffa, P., 1925. Sulle relazioni fra costo e quantità prodotta. Annali di Economia, 2, pp. 277-328.

Sraffa, P., 1926. The laws of returns under competitive conditions. Economic Journal, 36, pp. 535-50.

Sraffa, P., 1930. A Criticism and Rejoinder, Symposium on "Increasing returns and the representative firm". Economic Journal, 40, pp. 89-93.

Sraffa, P., 1960. Production of Commodities by Means of Commodities. Prelude to a Critique of Economic Theory. Cambridge: Cambridge University Press. 